\title{
PENGARUH SELF EFFICACY PESERTA DIDIK TERHADAP MINAT BERWIRAUSAHA DI KELAS XII SMK NURUL HUDA SUKARAJA
}

\author{
Ainun Jariyah $^{1}$, Khafid Ismail ${ }^{2}$, dan Siti Afifah $^{3}$ \\ ${ }^{1,2}$ STKIP Nurul Huda \\ *E-mail: : ainunassyarifah@gmail.com
}

\begin{abstract}
Abstrak: Self efficacy mempunyai peranan penting dalam memotivasi peserta didik sehingga peserta didik SMK tidak hanya membutuhkan kreativitas melainkan juga self efficacy agar mampu menghadapi tantangan dan persaingan era globalisasi. Dalam menghadapi era globalisasi setiap peserta didik diharapkan untuk berjuang secara gigih dengan melalui pencapaian hasil belajar yang maksimal.Penelitian ini bertujuan untuk mengetahui seberapa besar pengaruh self efficacy peserta didik kelas XII SMK Nurul Huda Sukaraja. Penelitian ini merupakan penelitian kuantitatif dengan desain penelitian expost facto. Populasi penelitian ini seluruh siswa kelas XII SMK Nurul Huda Sukaraja yang berjumlah 70 siswa, dengan seluruh populasinya akan digunakan sebagai sampel penelitian. Teknik pengumpulan data digunakan angket untuk variabel Self Efficacy $(\mathrm{X})$ dan Minat Berwirausaha $(\mathrm{Y})$. Analisis datanya menggunakan regresi linier sederhana. Hasil penelitian menunjukkan bahwa : (1) Self Efficacy tergolong dalam kategori sedang dengan hasil kategorisasi menunjukkan angka $52,9 \%$.(2) Minat Berwirausaha tergolong sedang dengan hasil kategorisasi menunjukkan angka $62,9 \%$. (3) Self Efficacy berpengaruh positif dan signifikan terhadap Minat Berwirausaha, yang dibuktikan dengan $\mathrm{T}_{\text {hitung }}$ sebesar 9,469 dan $T_{\text {tabel}}$ Sebesar1,99547 sehingga $T_{\text {hitung }}$ lebih besar dari $T_{\text {tabel }}$, dan variabel Self Efficacy memberikan sumbangan efektif sebesar $57 \%$ terhadap Minat Berwirausaha peserta didik,dan sisanya dipengaruhi faktor lain yang tidak diteliti.
\end{abstract}

Kata Kunci: Self Efficacy, Minat Berwirausaha.

\section{PENDAHULUAN}

Minat berwirausaha diawali dari adanya rasa ketertarikan dan kebutuhan untuk mengembangkan ilmu pengetahuan. Menurut Herianti (2017) Minat diartikan sebagai suatu kondisi yang terjadi apabila seseorang melihat ciri-ciri atau arti sementara situasi yang dihubungkan dengan keinginan-keinginan atau kebutuhankebutuhannya sendiri, oleh karena itu apa yang dilihat seseorang sudah tentu akan membangkitkan minatnya sejauh apa yang dilihat itu mempunyai pengaruh dengan kepentingannya sendiri. Minat merupakan faktor penting untuk memulai suatu pekerjaan karena jika seorang individu memiliki minat terhadap objek tertentu, maka akan cenderung memberikan perhatian yang lebih besar dalam mencapai suatu tujuan yang telah ditetapkan dapat dikerjakan dengan hasil yang baikNurhasan Dkk (2018). Peserta didik SMK harus memiliki minat yang tinggi terhadap pembukaan unit usaha yang baru.Minat yang dimaksudkan disini adalah minat berwirausaha. 
Berdasarkan observasi yang dilakukan peneliti diperoleh data terkait minat berwirausaha peserta didik sebenarnya telah memiliki bekal pengetahuan, baik dari teori maupun dari pengalaman praktik industri namun hal tersebut ternyata belum memunculkan efikasi dirinya setelah mendapatkan pengetahuan kewirausahaan. Sebagian siswa belum tahu apa yang akan dilakukan setelah lulus, padahal jika peserta didik yakin atau mempunyai efikasi diri yang tinggi dan mempunyai minat, maka untuk berwirausaha masa depannya akan terjamin. Kecilnya minat berwirausaha peserta didik SMK Nurul Huda Sukaraja sangat disayangkan. Menurut Mustofa (2014) Peserta didik seharusnya lebih memahami bahwa lapangan pekerjaan yang ada tidak mungkin menyerap semua lulusan SMK.Kewirausahaan dapat diterapkan di berbagai bidang pekerjaan dan kehidupan. Kewirausahaan juga sangat berguna untuk masa depan dan dapat menyelamatkan siswa dari pengangguran ketika lulus nanti (Putra, 2017).

Self efficacy mempunyai peranan penting dalam memotivasi peserta didik sehingga peserta didik SMK tidak hanya membutuhkan kreativitas melainkan juga self efficacy agar mampu menghadapi tantangan dan persaingan era globalisasi (Farida dan Nurkhin, 2016) .Dalam menghadapi era globalisasi setiap peserta didik diharapkan untuk berjuang secara gigih dengan melalui pencapaian hasil belajar yang maksimal. Rendahnya intensi berwirausaha diantaranya peserta didik masih ragu-ragu dan takut gagal sehingga peserta didik tidak siap menghadapi rintangan yang ada. Keragu-raguan dan ketakut gagalan yang dimiliki menyebabkan keyakinan terhadap kemampuan yang dimiliki peserta didik bahwa dirinya akan berhasil dalam berwirausaha menjadi rendah. Keyakinan terhadap kemampuan yang dimiliki individu bahwa dirinya akan berhasil dalam melakukan suatu tugas disebut selfefficacy (Greogory 2011:212).

Self efficacy diduga mempunyai pengaruh terhadap intensi peserta didik SMK untuk berwirausaha. Apabila individu memiliki self efficacy yang tinggi dan merasa bahwa dirinya mampu berwirausaha maka akan semakin tinggi pula intensi yang dimiliki individu untuk berwirausaha, sehingga individu akan berusaha semaksimal mungkin dan melakukannya dengan baik. Sebaliknya, individu dengan self efficacy yang rendah merasa bahwa dirinya tidak mampu untuk berwirausaha maka intensi yang dimiliki untuk berwirausaha pun akan semakin rendah. Dari Uraian di atas maka untuk mengetahui apakah terdapat pengaruh antara self efficacy terhadap jiwa kewirausahaan perlu adanya penelitian lebih lanjut, adapun tujuan penelitian ini yakni untuk mengetahui seberapa besar self efficay, seberapa besar minat berwirausaha peserta didik dan apakag terdapat pengaruh anatara self efficacy terhadap minat berwirausaha peserta didik di SMK Nurul Huda.

\section{METODE}

Jenis penelitian yang digunakan ialah penelitian kuantitatif dengan uji kausalitas.Populasi adalah wilayah generalisasi yang terdiri atas objek atau subjek yang mempunyai kualitas dan karakteristik tertentu yang ditetapkan oleh peneliti untuk dipelajari dan kemudian ditarik kesimpulannya (Sugiyono, 2012:80).Berdasarkan pengertian diatas maka peneliti menetapkan yang menjadi 


\section{PENGARUH SELF EFFICACY PESERTA DIDIK TERHADAP MINAT BERWIRAUSAHA DI KELAS XII SMK NURUL HUDA SUKARAJA}

populasi adalah seluruh kelas XII SMK Nurul Huda Sukaraja Tahun Pelajaran 2020/2021.

Tabel 3.

Populasi Penelitian

\begin{tabular}{|l|l|l|}
\hline No & Kelas & Jumlah \\
\hline 1. & XII Multimedia & 25 Siswa \\
\hline 2. & XIIAkuntansiLembaga & 20 Siswa \\
\hline 3. & XIIOTK. Perkantoran & 25 Siswa \\
\hline & Jumlah & $\mathbf{7 0 ~ S i s w a ~}$ \\
\hline
\end{tabular}

Sumber : TU SMK Nurul Huda Sukaraja

Karena jumlah populasinya tidak lebih besar dari 100 orang responden, maka penulis mengambil $100 \%$ jumlah populasi yang ada di kelas XII SMK Nurul Huda Sukaraja yaitu sebanyak 70 responden. Dengan demikian penggunaan seluruh populasi tanpa harus menarik sampel penelitian sebagai unit observasi disebut sebagai teknik sensus atau sampel jenuh.

\section{TEKNIK ANALISIS DATA}

Teknik analisis data adalah suatu cara yang dilakukan untuk mengolah data agar dihasilkan suatu kesimpulan yang tepat. Dalam penelitian ini, data ditabulasikan dan dianalisis secara regresi sederhana, serta menggunakan teknik korelasi product moment.

Analisis Regresi Linier Sederhana

Analisis regresi linier sederhana ini digunakan untuk menguji bagaimana pengaruh masing-masing variabel independen $(X)$ terhadap variabel dependen $(\mathrm{Y})$ yang diformulasikan dalam bentuk persamaan sebagai berikut : $\mathbf{Y}=\mathbf{a}+\mathbf{B x}$

Sedangkan untuk nilai konstanta a dan b dengan menggunakan rumus sebagai berikut:

$$
\begin{gathered}
a=\frac{\sum Y_{i} \sum X_{i}^{2}-\sum X_{i} \sum X_{i} Y_{i}}{n \sum X_{i}^{2}-\sum X_{i}{ }^{2}} \\
b=\frac{n \sum X_{i} Y_{i}-\sum Y_{i} \sum X_{i}}{n \sum X_{i}^{2}-\sum X_{i}^{2}}
\end{gathered}
$$

Keterangan:

$Y=$ Variabel dependen

$\alpha=$ Harga $Y$ ketika $X=0$ (harga konstan)

$b=$ koefisien regresi

$X=$ Variabel dependen 
Kemudian untuk mengetahui kuat atau lemahnya hubungan antara variabel dependen dengan variabel independen dihitung koefisien korelasi. Jenis korelasi yang bisa digunakan pada hubungan variabel garis lurus (linier) adalah korelasi Pearson product moment ( $\mathrm{r}$ ) adalah sebagai berikut:

$$
r_{x y}=\frac{N \sum x Y-\left(\sum x\right)\left(\sum Y\right)}{\sqrt{\left[N \sum x^{2}-\left(\sum x^{2}\right)\right\}\left\{N \sum Y^{2}-\left(\sum Y^{2}\right)\right\}}}
$$

Ket :

$r_{x y}=$ Koefisien korelasi antara variabel $X$ dan variabel $Y$

$\mathrm{N}$ = Jumlah responden

$\Sigma X=$ Jumlah skor variabel bebas

$\Sigma Y=$ Jumlah skor variabel terikat (Sudijono, 2010:206)

Setelah korelasi dihitung dapat dilanjutkan dengan menghitung koefisien determinasi.Koefisien determinasi ini berfungsi untuk mengetahui besarnya pengaruh variabel independen terhadap variabel dependen. Dalam penggunaannya, koefisien determinasi ini dinyatakan dalam persentase (\%) dengan rumus sebagai berikut :

$K d=r^{2} \times 100 \%$ (Sugiyono, 2010 :231).

Keterangan :

$\mathrm{Kd}=$ koefisien determinasi

$r \quad=$ koefisien korelasi

\section{HASIL DAN PEMBAHASAN}

\section{Hasil}

Persamaan Regresi Linier Sederhana

Persamaaan regresi linier sederhana digunakan untuk

merumuskanpersamaan regresi dan untuk mengetahui pengaruh antara variabel independen $(X)$ dengan variabel dependen $(Y)$. Hasil yang diperoleh setelah data diolah dengan bantuan program SPSS V21 sebagai berikut :

Tabel 4.13. Hasil Uji Regresi

\section{Coefficients $^{a}$}

\begin{tabular}{|l|l|l|l|l|l|}
\hline \multirow{3}{*}{ Model } & \multicolumn{2}{|l|}{$\begin{array}{l}\text { Unstandardized } \\
\text { Coefficients }\end{array}$} & $\begin{array}{l}\text { Standardized } \\
\text { Coefficients }\end{array}$ & T & Sig. \\
\cline { 1 - 3 } & B & Std. Error & Beta & \\
\hline
\end{tabular}




\section{PENGARUH SELF EFFICACY PESERTA DIDIK TERHADAP MINAT BERWIRAUSAHA DI KELAS XII SMK NURUL HUDA SUKARAJA}

\begin{tabular}{|c|c|c|c|c|c|}
\hline Constant & 25,466 & 3,740 & & 6,809 &, 000 \\
\hline $\begin{array}{c}\text { Self } \\
\text { efficacy }\end{array}$ & 1,078 & ,112 &, 760 & 9,649 &, 000 \\
\hline
\end{tabular}

a. Dependent Variable: minat berwirausaha

Berdasarkan analisis data menggunakan bantuan program SPSS V21, diperoleh persamaan regresi sebagai berikut:

1) Nilai konstanta sebesar 25,466 menunjukkan bahwa jika tidak ada variabel self efficacy $(X)$ maka nilai konstanta Minat Berwira usaha $(Y)$ sebesar 25,466 .

2) Nilai self efficacy $(X)$ sebesar 1,078 dengan nilai positif. Hal ini mengandung arti bahwa setiap penambahan $1 \%$ tingkat self efficacy $(\mathrm{X})$, maka Minat berwirausaha $(\mathrm{Y})$ meningkat sebesar 1,078 .

Karena nilai koefisien regresi bernilai positif $(+)$, maka dengan demikian dapat dikatakan bahwa self efficacy $(\mathrm{X})$ berpengaruh positif terhadap Minat berwirausaha $(Y)$. Sehingga persamaan regresi liniernya adalah :

$$
\begin{aligned}
& Y=a+B x \\
& Y=25,466+1,078 X
\end{aligned}
$$

\section{Pembahasan}

Dari hasil penelitian menunjukkan bahwa terdapat pengaruh positif dan signifikan self efficacy terhadap minat berwirausaha di kelas XII SMK Nurul Huda Sukaraja .Semakin tinggi self efficacy, maka semakin tinggi minat berwirausaha pada peserta didik. Sebaliknya semakin rendah self efficacy maka semakin rendah minat berwirausaha pada peserta didik kelas XII SMK Nurul Huda Sukaraja. Dari hasil analisis dengan menggunakan regresi linier sederhana, diperoleh $T_{\text {hitung }}$ sebesar 9,469 dan $T_{\text {tabel }}$ sebesar 1,99547., sehingga $T_{\text {hitung }}$ lebih besar dari $T_{\text {tabel }}(9,469$ $>1,99547)$. Hal ini menunjukkan bahwa self efficacy peserta didik $(X)$ mempunyai pengaruh secara signifikan terhadap Minat berwirausaha $(\mathrm{Y})$. Dengan demikian dapat dikatakan bahwa semakin tinggi self efficacy, akan semakin tinggi pula Minat berwirausaha Pada peserta didik, dan begitu pula sebaliknya.

Melalui analisis regresi sederhana, dapat diketahui bahwa koefisien determinan $R^{2}$ sebesar 0,57 . Secara bersama-sama variabel self efficacy memberikan sumbangan efektif sebesar $57 \%$ terhadap Minat Berwirausaha, dan sisanya dipengaruhi faktor lain yang tidak diteliti.

\section{SIMPULAN}

Berdasarkan hasil analisis dan pembahasan tentang pengaruh self eficacy peserta didik terhadap minat berwirausaha di kelas XII SMK Nurul Huda Sukaraja dapat ditarik kesimpulan sebagai berikut : 
1. Self efficacy kelas XII SMK Nurul Huda Sukaraja dengan jumlah 70 siswa terbagi dalam tiga kategori, yaitu kategori rendah terdiri dari 14 orang $(20,0 \%)$, kategori sedang terdiri dari 37 siswa (52,9\%), kategori tinggi terdiri dari 19 siswa $(27,1 \%)$.

2. Minat berwirausaha di kelas XII SMK Nurul Huda dengan jumlah 70 siswa terbagi dalam tiga kategori, yaitu kategori rendah terdiri dari 10 siswa $(14,3 \%)$, kategori sedang terdiri dari 44 siswa $(62,9 \%)$, kategori tinggi terdiri dari 16 siswa $(22,9 \%)$.

3. Self efficacy berpengaruh positif dan signifikan terhadap minat berwirausaha di kelas XII SMK Nurul Huda Sukaraja. Hal ini dibuktikan dengan $\mathrm{T}_{\text {hitung }}$ sebesar 9,649 dan $T_{\text {tabel }}$ sebesar 1,99547 sehingga $T_{\text {hitung }}$ lebih besar dari $T_{\text {tabel }}(9,649$ $>1,99547$ ), diperoleh koefisien determinan $R^{2}$ sebesar 0,57 , dan variabel self efficacy memberikan sumbangan efektif sebesar 57\% terhadap Minat Berwirausaha Pada Siswa, dan sisanya dipengaruhi faktor lain yang tidak diteliti. Dengan demikian, semakin tinggi self efficacy semakin tinggi pula minat berwirausaha pada peserta didik. demikian pula sebaliknya semakin rendah self efficacy maka semakin rendah pula minat berwirausaha peserta didik.

\section{UCAPAN TERIMAKASIH}

Ucapan terimakasih ditujukan kepada STKIP Nurul Huda Sukaraja yang menjadi bagian perjalanan menempuh pedidikan sarjana pendidikan ekonomi dan seluruh pihak yang telah ikut serta dalam pembuatan skripsi penulis. Kepada kedua orang tua dan kedua pembimbing penulis, serta teman-teman seperjuangan yang telah menorehkan banyak cerita dan juga pengalaman. Terimakasih juga kepada team journal UTILITY STKIP Nurul Huda.

\section{REFERENSI}

Nurhasan, R., Purnomo, E., \& Sinaga, R. M. (2018). Pelaksanaan Praktik Kerja Industri Dalam Upaya Meningkatkan Minat Berwirausaha. Jurnal Studi Sosial/Journal of Social Studies, 6(1).

Herianti, E., \& Marundha, A. (2017). The Effect of Business Strategy on Manipulation of Real Activities.

Mustofa, M. A. (2014). Pengaruh pengetahuan kewirausahaan, self efficacy, dan karakter wirausaha terhadap minat berwirausaha pada siswa kelas XI SMK Negeri 1 Depok Kabupaten Sleman. Skripsi. Yogyakarta: UNY.

ADI PUTRA, N. A. N. A. N. G. Pengaruh Pengetahuan Kewirausahaan dan Sikap Berwirausaha Terhadap Minat Berwirausaha Siswa Kelas XI SMA Negeri 11 Kota Jambi. JURNAL PENGARUH PENGETAHUAN KEWIRAUSAHAAN DAN SIKAP BERWIRAUSAHA TERHADAP MINAT BERWIRAUSAHA SISWA KELAS XI SMA NEGERI 11 KOTA JAMBI. 


\section{PENGARUH SELF EFFICACY PESERTA DIDIK TERHADAP MINAT BERWIRAUSAHA DI KELAS XII SMK NURUL HUDA SUKARAJA}

Farida, S., \& Nurkhin, A. (2016). Pengaruh pendidikan kewirausahaan, lingkungan keluarga, dan self efficacy terhadap minat berwirausaha siswa SMK program keahlian Akuntansi. Economic Education Analysis Journal, 5(1).

Gregory, C., Darby-Dowman, K., \& Mitra, G. (2011). Robust optimization and portfolio selection: The cost of robustness. European Journal of Operational Research, 212(2), 417-428.

Sugiyono. (2012). Statistika untuk penelitian. Bandung: Alfabeta 